\title{
Global Changes, Regional Impacts: Climate Change in the Middle East
}

\section{Pauline McNamara, Bern}

\section{Introduction}

In terms of necessity for sustaining life, water can be considered our most essential natural resource. Especially in areas where it is scarce, its value increases to the point where conflicts arise over its shared use. The Middle East region presents an example of such a water access conflict, exacerbated by long term political antagonism (McCAFFREY 1993). Yet another critical factor to be considered in this precarious situation is climate change, where the possibility of modified temperatures and precipitation could shrink an already limited resource.

The work described here deals with possible global changes expressed at the regional level, and the utility (and limits) of global scale models in approaching these potential problems.

\subsection{The Context:}

\section{Modelling as a Resource Planning Tool}

Evidently, projecting water resource use requires a model which integrates many of these various sectors. This is the aim of the CLIMSOC model, which strives to integrate socio-economic and climatic factors contributing to water use in a region where water resources are shared, in this case the Middle East, in order to project future water use based on a variety of parameters (LUTERBACHER \& WIEGANDT 1997).

The work described here was carried out in the context of the CLIMSOC model in the following manner: Precipitation inputs to CLIMSOC are to be provided from a general circulation model, also referred to as a global climate model, or GCM (McGuffie \& HeNDERSONSELLERS 1997). An essential first step before applying the GCM results for a future period is to test GCM output for a recent period against available observed data, validating the accuracy (or revealing the inaccuracy) of the GCM when applied at the regional scale. Hopefully, then, one could pinpoint shortfalls to be corrected before introducing results for a future period into the CLIMSOC model. This comparison between GCM results and observational data is the focus of this paper, using the Middle East region as the target area.

\subsection{The Study Area: \\ Water Scarcity and Political Conflict}

The Middle East region, specifically the Jordan River catchment basin, presents itself as a fitting example of an area struggling with conflict over already limited water resources. Whether or not climate change affects water availability in the region, population growth will continually increase pressure on water supply. Jordan and Israel already withdraw more water from the system than can be renewed. Distribution of scarce water requires a very sophisticated water management system, as for example in Israel (GLEICK 1993b). As in the case of the Jordan River watershed, this situation can lead to considerable political tensions. Following are examples of the conflict situation, based on STEPHEN C. MCCAFFREY's «Water, politics and international law», in «Water in Crisis - A Guide to the World's Fresh Water Resources», edited by Peter H. GleicK (1993a). Extensive references are provided there for further reading (MCCAFFREY 1993).

As it flows from its sources down to the Dead Sea, the 93 kilometers of the Jordan River contact several borders: Lebanon, Syria, Jordan, Israel and the Palestinian Territories. The headwaters are made up of three streams, each located in a different country. Since 1967, Israel controls these areas and therefore all the headwaters of the Jordan. The Jordan River has two tributaries, one entirely in Jordan, the other forming the border between Jordan and its neighbors, Syria and Israel. This second tributary contributes $40 \%$ of the Jordan's total flow. Overall, $77 \%$ of the Jordan River's water originates in Arab countries (Fig. 1).

Water resources can clearly be considered a significant element contributing to hostilities in this region. One such case is the situation leading up to the 1967 war, in which Israel seized the West Bank, declaring the water of the West Bank and the Gaza Strip a strategic resource under military control. In 1964, partly in response to Israel's construction of the National Water Carrier (diverting water from Lake Tiberias to Tel Aviv and the Negev Desert), Arab states developed a plan called the Headwater Diversion Project. This would divert Jordan River headwaters and store them in the planned Mukheiba Dam, which has since not been constructed. According to estimates, this would have cut the amount of water available for the National Water Carrier by half.

Israel considered the diversion to be a violation of its sovereign rights, and launched military strikes against the works after construction began. They culminated in April 1967 with air strikes deep within Syria. P. BEAUMONT stated during the 1991 Conference on Transboundary Water Disputes in the Middle East that «the increase in water-related Arab-Israeli hostility was a major factor leading to the 1967 June War» (MCCAFFREY 1993: 93).

Indeed, the limestone aquifer located below the West Bank provides one quarter of Israel's water. The political significance of water is apparent in the occupied ar- 


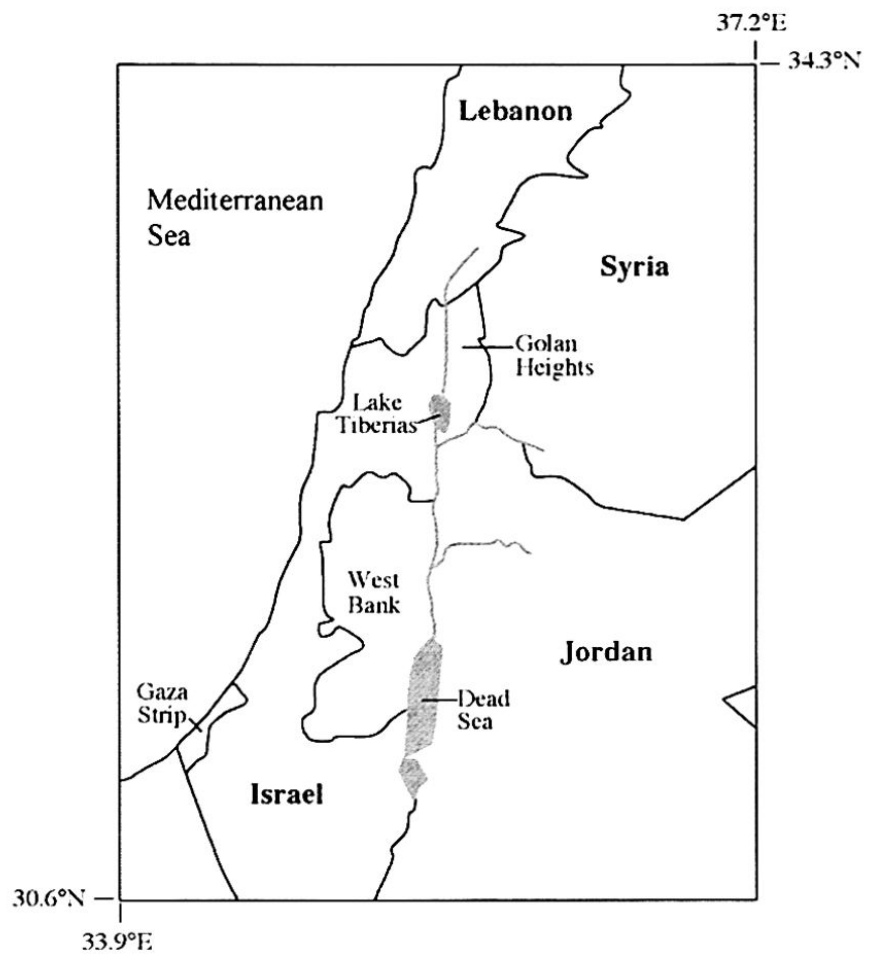

Fig. 1: The Jordan River and its riparian territories Der Jordan-Fluss und angrenzende Territorien La rivière Jordan et les territoires bordières

eas, where water use is strictly controlled. The inequitable nature of that control is expressed through the absence of running water in many Arab villages (about half) alongside some Israeli settlements that have swimming pools (MCCAFFREY 1993). However, neither Palestinian claims of increasing Israeli withdrawals nor any opposing claims from Israelis can be verified, as Israel deems water statistics to be state secrets and therefore does not release them (GeHriger 1999, GLEICK 1993b).

Obviously, traditional animosities are rendered more acute over water scarcity. In spite of accords signed by the conflict parties, recent developments show the potential role that climate change could play in the Middle East political arena: after declaring 1999 to be an official drought year, Israel announced in April that it would deliver only one half of the previously agreedupon quantity of water to Jordan (GEHRIGER 1999, Middle East Water Commission 1995). Obviously, any hope for agreement over equitable sharing of water resources hinges on the current Middle East Peace Conference; at the same time, an accord over water access is clearly a prerequisite for progress in these peace talks. The possibility of climatic changes renders this all the more urgent.

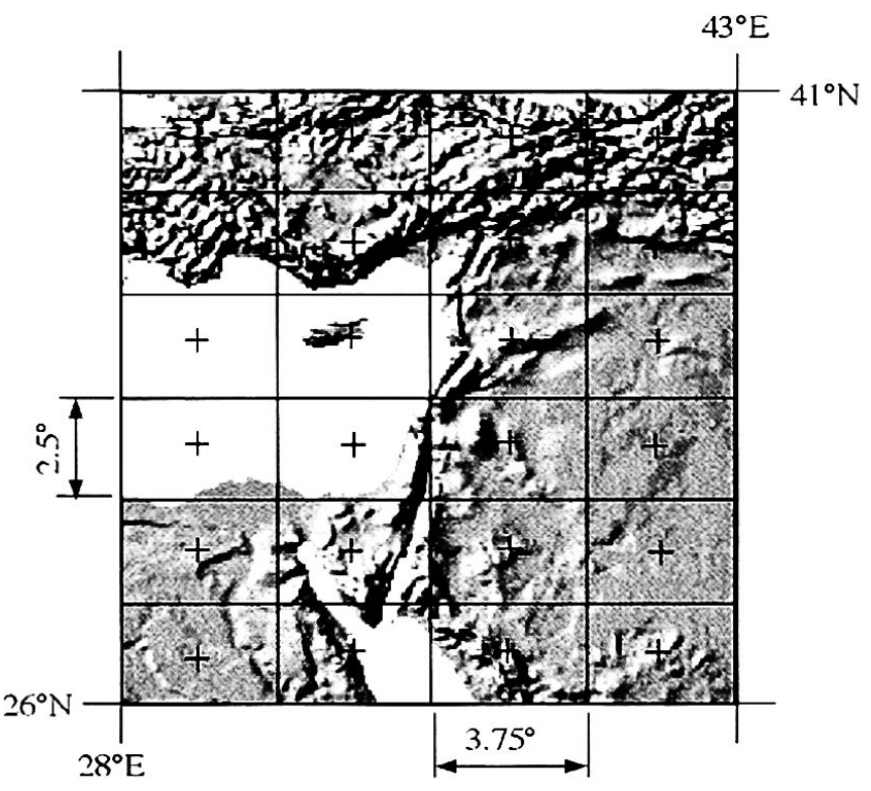

Fig. 2: The GCM data points and corresponding grid cells of the study area

Das GCM-Raster des Studiengebietes

La grille GCM de la région étudiée

\section{Methodology and Data}

Planning for future water resources in this region obviously demands examination of multiple factors. An integrated approach, as proposed by the CLIMSOC model, can provide this type of framework. GCMs, though conceived to simulate climate primarily at the global scale, represent a powerful means of projecting future climate conditions. The utility of models as planning tools is clear, particularly in view of possible changes in climatic conditions and their subsequent impacts on various sectors of society.

A necessary preliminary step to employing GCM projections involves testing present period scenarios against observation data. This comparison between GCM-produced precipitation and precipitation data from an observed climatology constitutes the core of the work described here. The two sets of precipitation data were compared for the period 1961-1990, the time scale being limited to monthly averages over the 30 year period.

The GCM data are the results of HADCM2, an acronym for Hadley Centre Coupled Model v2, indicating the model's origin: the Hadley Centre for Climate Prediction and Research, Meteorological Office, United Kingdom (Johns et al. 1997, Mitchell \& Johns 1997). The model is a three dimensional, coupled ocean-atmosphere model with a spatial resolution of $2.5^{\circ}$ latitude by $3.75^{\circ}$ longitude. A $15^{\circ} \times 15^{\circ}$ study area ( 24 grid points) was chosen for this project: $28^{\circ} \mathrm{E}$ to $43^{\circ} \mathrm{E}$ longitude and $26^{\circ} \mathrm{N}$ to $41^{\circ} \mathrm{N}$ latitude (Fig. 2). In this region, 

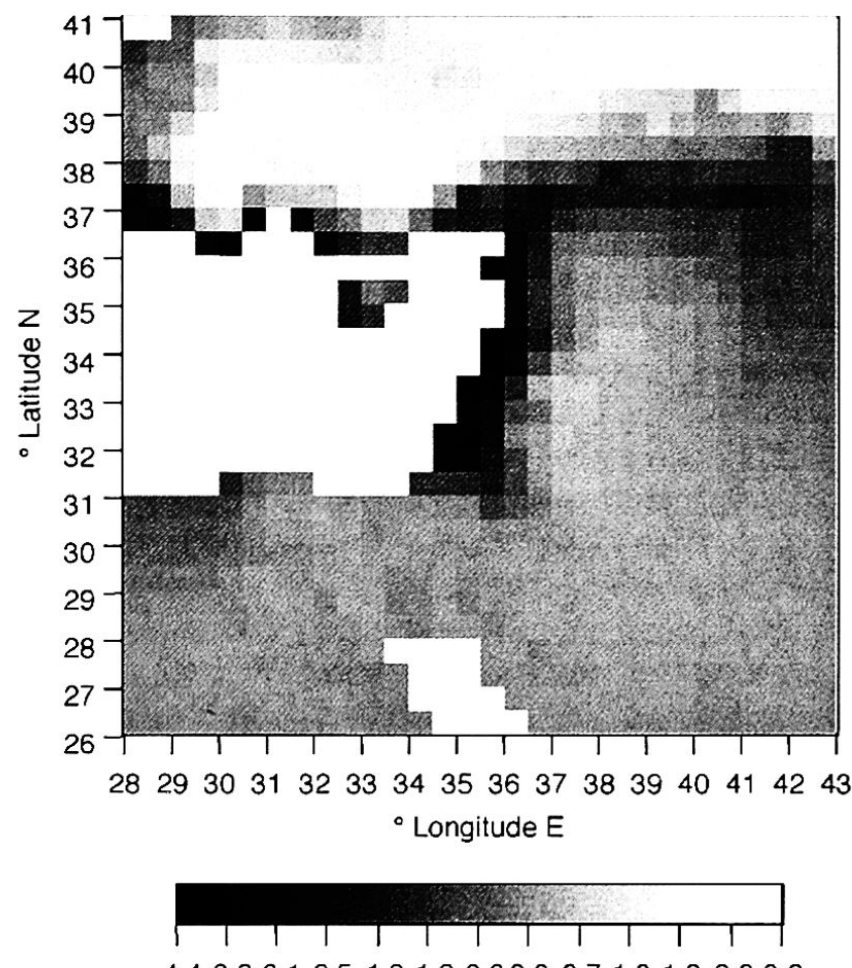

-4.4-3.8-3.1-2.5-1.9-1.2-0.60.0 0.7 1.3 1.92.63.2

GCM vs. Observed January Precipitation 1961-1990 (mm/day)

Fig. 3: Over- and underestimates of GCM precipitation, January 1961-1990

Vom GCM über- und unterschätzte Niederschlagsmengen, Januar 1961-1990

Sur-et sousestimations des précipitations simulées par le GCM, janvier 1961-1990

each grid cell represents approximately $277 \mathrm{~km}$ in the north-south direction, and from 315 to $375 \mathrm{~km}$ in the east-west direction.

A gridded climatology of monthly means is used to represent observed precipitation. Developed at the University of East Anglia's Climatic Research Unit, the $0.5^{\circ} \mathrm{x}$ $0.5^{\circ}$ grids are produced using thin plate spline interpolations of station data as a function of latitude, longitude and elevation (NEw et al. 1999).

A basic methodological consideration in comparing the global data with the observed climatology concerns scale. Two scales are involved: the model data is gridded at $3.75^{\circ}$ longitude by $2.5^{\circ}$ latitude, whereas the observed climatology has a $0.5^{\circ} \times 0.5^{\circ}$ grid. A fundamental question to be answered, therefore, is: which scale should be used to compare the two sets of values? In order to preserve the information of each dataset, the comparisons were carried out at both scales. More extensive descriptions of methodology are provided in MCNAMARA (1999).
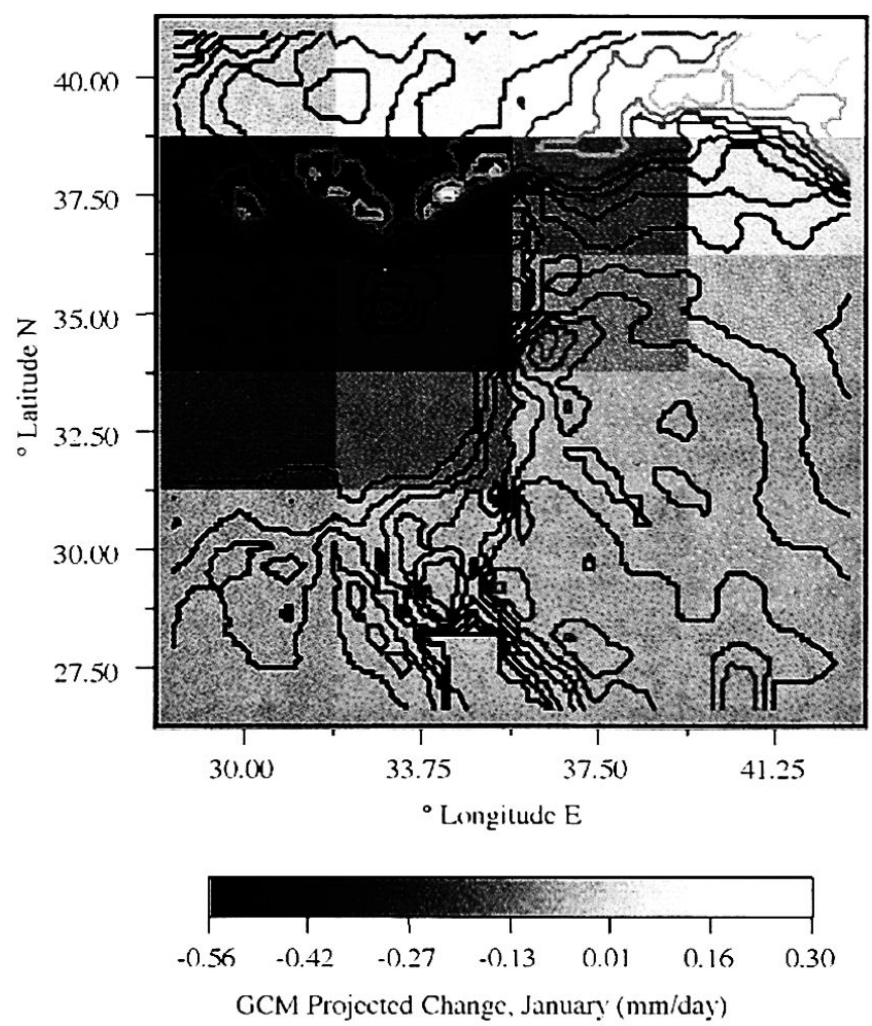

Fig. 4: GCM projected precipitation change for January 2010-2039 with respect to 1961-1990 (Contour lines represent topography)

Vom GCM prognostizierte Niederschlagsänderungen für Januar 2010-2039 bezogen auf 1961-1990 (Höhenkurven stellen die Topographie dar)

Changements de précipitation simulés par le GCM pour janvier 2010-2039 par rapport à 1961-1990 (Courbes de niveau indiquent la topographie)

To compare at the observed data's $0.5^{\circ}$ scale, the GCM results were interpolated bi-linearly, after necessary steps of coordinate conversion to ensure a more accurate representation of distance (BUGAYEVSKY \& Schnyder 1995, Golden Software Inc. 1990). In order to present quantitative differences for each GCM grid point value, thus comparing at the GCM scale, the observed data were either averaged over the entire corresponding grid cell (as in OSBORN \& HULmE 1998), or an average of only the observed points located closest to the GCM point (up to 4 observed points) was calculated.

\section{Comparison of General Circulation Model Data with Observed Climatology}

The main differences between GCM projections and the observed climatology have been found as overestimates of the GCM in the northern part of the study area in both winter and summer, and as underestimates in winter 
along the northern and eastern Mediterranean coast. The highest underestimates occur over areas that are smaller than one GCM grid cell, and are therefore better detected through comparisons at the finer resolution of the $0.5^{\circ}$ scale (Fig. 3). This is linked to the observed precipitation pattern of this region, where maximal amounts fall along a narrow strip of the coast, and then decrease sharply inland. Such high spatial variability is impossible to capture at the GCM's spatial scale.

Several region-wide statistics were also employed to compare the GCM data and the observed climatology: region-wide totals and averages, pattern correlation and root mean square error. Though the GCM usually produced higher overall total and average precipitation, the monthly variations are fairly well reproduced. Pattern correlations are higher in summer than winter, and root mean square error is lower in summer months than in the winter period. These last two comparison results are logically consistent - since rainfall is more frequent and more substantial in winter than in summer, it is more difficult to produce accurate winter projections.

It is clear that variations at the subgrid scale cannot be reproduced by the GCM: the scale of the model hinders its ability to project precipitation as it occurs at the regional scale. Two features significant to rainfall patterns in this region are not «seen» by the global model: the rain shadow in central Turkey, and the steep rain gradient inland from the coast. Observed maximum amounts fall over limited areas and vary considerably at the subgrid scale. The GCM value, when taken as an average over each grid box (more appropriately), masks the variance within each grid.

\section{Exploring Data Relationships}

In addition to the previous descriptive indicators, further analyses were carried out to examine the spatial distribution of January precipitation in the two datasets, particularly in terms of its association with other factors. The three factors considered are spatial continuity, topography and continentality.

Spatial continuity (autocorrelation), a characteristic of most earth science datasets, is expressed through data values that are grouped together rather than being randomly located in space. The distance and orientation of data grouping are revealed using variography analyses (ISAaKs \& SRIVASTava 1989, Bonham-CaRTER 1994, PANNATIER 1996). It was found that January precipitation displays autocorrelation up to a certain distance in both GCM and observed data, but that observed data show more variability over shorter distances. Variography further illustrated that the orientation of data clustering is not always the same in observed and GCM data, depending on the sector considered.
Using correlation coefficient $r$, precipitation distribution was then examined for associations with topography and continentality. Correlations of rainfall with topography uncovered differences between GCM and observed precipitation, with GCM rainfall showing in general a stronger association with elevation, which is consistent with assumptions regarding precipitation's determinant factors. The $r$ values for observed data, however, were largely influenced by extreme points of higher observed precipitation which occur at lower elevations; these extreme points cannot be reproduced at the GCM scale. Correlations between precipitation and distance from the Mediterranean showed rainfall having a stronger association with continentality than with topography. Continentality displayed negative correlations up to certain distances. This distance was greater for the GCM data, which also had lower $r$ values than observed precipitation.

\section{Projected Climate Change: Implications for the Future}

Having located probable areas of the GCM results requiring adjustment, it is interesting then to look at the HADCM2 projections for the period 2010-2039. These are shown in Fig. 4, presented as change with respect to the period 1961-1990. Acknowledging that it is preferable to consider projections as a range of possible changes stemming from several models, the range of the Hadley Centre model's results agree generally with those presented by Wigley (1992).

It is interesting to note that, based on the comparisons carried out here, model error is often quantitatively much larger than projected change. Over the entire study area and all months, the model projections range from -0.59 to $+0.41 \mathrm{~mm} /$ day (corresponding to -21 to $+23 \%$ of averaged-observed precipitation at those points). The range of model error (GCM versus averaged-observed) is considerably greater: from -2.18 to $+3.04 \mathrm{~mm} /$ day (corresponding to -65 to $+203 \%$ of averaged-observed at those points). When presented as a percentage of observed rainfall, the projected changes alone are already considerable, and could require serious adaptations in water resources planning. Once model errors are «corrected», the resulting magnitude of projected change may well represent an urgent need for action in water management.

Taking into account the inherent uncertainty of model results, plus the corrections necessary to "downscale» global scale projections, substantial changes could be possible, and could be severe. Yet, in this area where resources are already strained beyond the limits of the renewable system, any change in the physical availability of water could present significant problems. This could seriously affect access to available water which, as mentioned earlier, is already a very delicate issue. 


\section{Concluding Remarks}

In conclusion, it is important to remember that the point here is not simply to highlight the shortcomings of global models. If any criticism were to be expressed, it would need to be directed at improper applications of GCM results, a problem which is related to an appreciation of the specificity of scale. Global general circulation models produce results at the global scale, and as such these results represent a useful tool for assessing conditions over the entire globe. Precipitation, though of course related to synoptic level circulation, is a phenomenon with many regional and local influences. Before employing GCM results, for example in a regionalscale model of water resource use such as CLIMSOC, it is necessary first to recognize local and regional influences and then to integrate them, in an appropriate manner, into the global setting.

\section{Literature Cited}

BARBER, G.M. (1988): Elementary Statistics for Geographers. - New York: The Guilford Press.

Beniston, M., M. Rebetez, F. Giorgi \& M.R. MariNUCCI (1994): An Analysis of Regional Climate Change in Switzerland. - In: Theoretical and Applied Climatology 49: 135-159.

BONHAM-CARTER, G.F. (1994): Geographic Information Systems for Geoscientists: Modelling with GIS. New York: Pergamon, Elsevier Science Inc.

Bugayevsky, L.M. \& J.R. Schnyder (1995): Map Projections, A Reference Manual. - London: Taylor and Francis Ltd.

Climatic Research Unit, University of East Anglia (1998) (online document): The Hadley Centre's Second Generation Coupled Ocean-Atmosphere GCM: HADCM2, www.cru.uea.ac.uk/link/experiments/2_experi_i ntro.html: 6 .

Gehriger, U. (1999): Am Jordan steht ein heisser Sommer bevor. - In: Tages Anzeiger, 19 April 1999: 10.

GleicK, P. (1994): Effects of Climate Change on Shared Fresh Water Resources. - In: MinTzer, I. (ed.) (1993): Confronting Climate Change - Risks, Implications and Responses. - Cambridge, Cambridge University Press: 127-140.

Gleick, P. (ed.) (1993a): Water in Crisis - A Guide to the World's Fresh Water Resources. - Oxford: Oxford University Press.

Gleick, P. (1993b): Water in the 21 st Century. - In: Gleick, P. (ed.) (1993a): Water in Crisis - A Guide to the World's Fresh Water Resources. - Oxford, Oxford University Press: 105-113.

Golden SofTware INC. (1990): Mapviewer User Manual. - Golden, Colorado USA: Golden Sofware Inc.

iPCC Intergovernmental Panel on Climate Change (1998): The Regional Impacts of Climate
Change - An Assessment of Vulnerability. - Working Group II, Special Report, Cambridge: University Press. IsaAKS, E.H. \& R.M. SRIVAStava (1989): Applied Geostatistics. - New York: Oxford University Press.

JoHns, T.C. et al. (1997): The second Hadley Centre coupled ocean-atmosphere GCM: model description, spinup and validation. - In: Climate Dynamics 13: 103134.

Luterbacher, U. \& E. Wiegandt (1998): Water Resource Conflicts: The Use of Formal Approaches. Graduate Institute of International Studies, Geneva, Switzerland, manuscript: 1-33.

Luterbacher, U. \& E. Wiegandt (1997): Toward an Integrated Model of Water Resource Use in Different Regions. - Graduate Institute of International Studies, Geneva, Switzerland, manuscript: 1-26.

McCaffrey, S.C. (1993): Water, Politics and International Law. - In: GLEICK, P. (ed.) (1993): Water in Crisis - A Guide to the World's Fresh Water Resources. - Oxford: Oxford University Press: 92-101.

McGuffie, K. \& A. Henderson-Sellers (1997): A Climate Modelling Primer. $-=2^{\text {nd }}$ Edition, West Sussex, England: Wiley \& Sons.

McNamara, P. (1999): Climate Change in the Middle East: Comparison of Global Climate Model Data and Observed Precipitation Data. - Master's Thesis, Institute of Geography, Fribourg University, Switzerland: 1128.

Middle East Water Commission (1995): Observations Regarding Water Sharing and Management: an Intensive Analysis of the Jordan River Basin with Reference to Long-distance Transfers. - In: Water Resources Development 11, 4: 351-375.

Mintzer, I. (ed.) (1993): Confronting Climate Change - Risks, Implications and Responses. - Cambridge: Cambridge University Press.

Mitchell, J.F.B. \& T.C. Johns (1997): On Modification of Global Warming by Sulfate Aerosols. - In: Journal of Climate 10: 245-267.

New, M., Hulme, M. \& P. Jones (1999): Representing Twentienth Century Space-Time Climate Variability I: Development of a 1961-1990 Mean Monthly Terrestrial Climatology. - In: Journal of Climate 12: 829-856. Osborn, T.J. \& M. Hulme (1998): Evaluation of the European Daily Precipitation Characteristics from the Atmospheric Model Intercomparison Project. - In: International Journal of Climatology 18: 505-522.

Pannatier, Y. (1996): Variowin: Software for Spatial Data Analysis in 2D. - New York: Springer.

Wigley, T.M.L. (1992): Future Climate of the Mediterranean Basin with Particular Emphasis on Changes in Precipitation. - In: Leftic, Milliman \& Sestini (eds.) (1992): Climate Change and the Mediterranean: Environmental and Societal Impacts of Climatic Change and Sea-level Rise in the Mediterranean Region. $-=$ United Nations Environment Program, Routledge, Chapman and Hall, New York 1: 15-44. 
Wigley, T.M.L. \& G. Farmer (1982): Climate in the Eastern Mediterranean and Near East. - In: BinTlifF, J.L. \& W. VAN ZeIST (eds.) (1982): Paleoclimates, Paleoenvironments and Human Communities in the Eastern Mediterranean Region in Later Prehistory. - = B.A.R. International Series 133, Oxford: 3-39.

\section{Summary: Global Changes, Regional Impacts: Climate Change in the Middle East}

In the Middle East, an area where pressure on water resources is intensified by political conflict and natural scarcity, the possibility of future climate change looms as yet another compounding factor. An integrated approach, taking economic, social, political and climate factors into consideration, is embodied in the CLIMSOC model. Before using global model data for a future period as input into the regional scale CLIMSOC model, the global climate model data must first be tested for the present period. The work summarised here examines monthly precipitation data from a Hadley Centre Global Climate Model, comparing it to an observed climatology, for the present period 1961-1990. The differences between the GCM and observed data are examined with an eye toward systematic discrepancies among the different months, spatial patterns and overall quantitative differences in precipitation. Finally, a glimpse at future precipitation, as estimated by the global climate model, is presented in the context of the comparison results.

\section{Zusammenfassung: Globale Änderungen, regionale Wirkungen: Klimaänderung im Nahen Osten}

Im Nahen Osten gesellt sich die Problematik einer Klimaänderung als möglicher Faktor, der in Zukunft Druck auf Wasserressourcen ausüben könnte, zu den bereits beträchtlichen Problemen wie politische Konflikte und natürlicher Wassermangel. Das CLIMSOC-Modell entspricht einem interdisziplinären Ansatz, der ökonomische, soziale, politische und klimatische Faktoren integriert. Bevor man die Resultate von globalen Modellen als klimatischen Input im regionalen Massstab des CLIMSOC-Modells brauchen kann, müssen diese ge- gen Messdaten «getestet» werden. Die in diesem Artikel kurz beschriebene Arbeit vergleicht monatliche Niederschlagsdaten eines globalen Klimamodells des Hadley Centre mit einer auf Messstationsdaten basierenden Klimatologie für den Zeitraum von 1961 bis 1990. Quantitative Unterschiede, räumliche Muster und regelmässige Niederschlagsabweichungen werden untersucht. Schliesslich werden die vom Modell simulierten zukünftigen Niederschlagsmengen im Kontext des vorliegenden Vergleiches präsentiert.

Résumé : Changements globaux, effets régionaux : changements climatiques dans le Moyen-Orient

Dans une région comme le Moyen-Orient, où la pression sur les ressources en eau est intensifiée par des conflits politiques et par une pénurie naturelle, les changements climatiques potentiels s'y ajoutent comme facteur menaçant. Le modèle CLIMSOC permet une approche intégrée, en prenant en compte des facteurs économiques, sociaux, politiques et climatiques. Pourtant, avant d'introduire les données d'un modèle climatique global (GCM) pour représenter les conditions futures dans le modèle CLIMSOC à l'échelle régionale, les données du modèle climatique global doivent subir d'abord un «test» de ses prévisions pour la période présente. Le travail résumé ici examine des données mensuelles de précipitations d'un modèle global du Hadley Centre, en les comparant à une climatologie observée de 1961 à 1990. On a examiné les différences entre les données observées et celles du GCM en vue de dévoiler des divergences systématiques, des répartitions spatiales et des différences quantitatives totales de précipitations. Enfin, on présente les estimations de précipitations futures du modèle du Hadley Centre dans le contexte des résultats de ces comparaisons.

Dipl.-Geogr. Pauline McNamara, Cäcilienstrasse 34, CH-3007 Bern.

e-mail: pmcnamara@access.ch 